\title{
EL IMPERIO DEL MARKETING POLÍTICO. CUANDO LAS IMÁGENES DESPLAZAN A LAS IDEAS*
}

\author{
Raúl Trejo Delarbre**
}

Fecha de recepción: enero 2000

Fecha de aceptación y versión final: abril 2000

\begin{abstract}
Resumen: Desde una perspectiva teórica se analizan las transformaciones de la política a partir de la presencia masiva de medios de comunicación y sondeos de opinión; que los ha convertido en representantes cotidianos de las opiniones ciudadanas. El creciente peso de la información audiovisual, con sus particularidades específicas, es considerado por el autor como un factor clave de la transformación de algunos elementos constitutivos básicos del proceso político democrático: campañas electorales, partidos políticos y candidatos.

Palabras Clave: Medios de comunicación, comunicación política, opinión pública, discurso político, campañas electorales.
\end{abstract}

Abstract: From a theoretic perspective the article analyzes the changes of politics related to the massive presence of media and opinion polls; these ones have appeared as the habitual representations of public opinions. The growing importance of audiovisual information, with its specific features is considered by this author as a key factor of the transformation of some constitutive elements of the democratic process: electoral campaings, political parties and candidates.

Key words: Mass media, political communication, public opinion, political discourse, electoral campaings.

Cada vez crece más la tendencia a considerar que los medios pueden ser el único espacio en donde pueda ser procesado el consenso político. Esa imagen de los medios coincide con el declive público de los partidos y con el desprestigio de la política tradicional, incluso de las formas de representación parlamentarias. En esta hora del descrédito que padecen los mecanismos tradicionales del quehacer político debido a faltas bien documentadas, pero también a causa de la magnificación mediática de sus abusos, los medios llegan a erigirse como los instrumentos de expresión -y presión- por excelencia en las sociedades modernas. Incluso, hay quienes piensan que "los medios de comunicación podrían estar en la vía, si es que no lo han logrado ya, de sustituir a los partidos políticos en su relación con la gente" (Fernández, 1996: 19 y ss.).

El marketing político, los foros televisivos y las encuestas, llegan a reemplazar a la persuasión cara a cara, a la discusión en las plazas públicas y a la expresión directa de los ciudadanos, como mecanismos para fabricar los consensos hoy en día. Los sondeos preelectorales, no sólo diagnostican qué piensa una sociedad en un instante específico sobre un problema concreto, sino además sus resultados llegan a ser tomados como pronósticos, lo cual conduce a tropiezos significativos en la evaluación de los procesos políticos. Los medios suelen reforzar las preferencias electorales que ya existen entre los potenciales votantes y sobre todo, actúan sobre quienes no han resuelto cómo será su sufragio: "la cobertura televisiva de la política y las elecciones, es considerada como influyente y como un mecanismo de modificación para aquellos que vacilan antes de la decisión electoral” (Collins y Butler, 1996: 64).

Los nuevos escenarios del cambio mundial nos remiten, una y otra vez, a los medios de comunicación de masas. No habría existido desmoronamiento del muro de Berlín en 1989, al menos en los términos pacíficos y súbitos en los que ocurrió, de no haber sido por la influencia de la televisión germano-occidental que se podía sintonizar, difundía valores y establecía contrastes en la antigua Alemania del Este. No habríamos sabido de la matanza en Tiananmen, al instante, de no ser gracias a los teléfonos celulares y a los faxes que divulgaron ese acontecimiento desde China, hacia todo el orbe. Quizá no se hubieran exacerbado tanto las tensiones en el Medio Oriente, de por sí soliviantadas con el guerrerismo de Saddam Hussein, de no haber sido por la expectación sensaciona-

* Esta ponencia, recupera y sintetiza elementos de un libro de próxima publicación.

$* *$ Investigador en el Instituto de Investigaciones Sociales de la Universidad Nacional Autónoma de México. Doctor en Sociología Director del semanario etcétera (www.etcetera.com.mx). Columnista político en el diarioLa Crónica de boy. $\square$ rtrejo@etcetera.com.mx 
lista e incluso provocativa de los medios que deseaban transmitir en vivo y en directo la guerra en el Golfo Pérsico. La vida y la muerte de la princesa Diana de Gales no habría sido conocida y deplorada universalmente, de no haber sido por los medios, paparazzos incluidos. El presidente Bill Clinton no habrá pasado a la historia como un personaje más conocido por sus vicisitudes personales que por su actitud como estadista, de no haber mediado la prensa sensacionalista -hábilmente aprovechada por sus rivales políticos-. Ya no es novedoso reconocer que vivimos en una aldea global, ni que la vida pública está organizada en gran medida en torno a las agendas establecidas por los medios. La política no existe, al menos como actividad que requiere del consenso social, si no es con el concurso de los medios de comunicación.

\section{CRECIENTE INFLUENCIA EN LA SOCIEDAD CONTEMPORÁNEA}

Los medios propician cambios políticos, sin duda. Pero esa capacidad no implica que tales cambios sean necesariamente en un sentido democratizador, o que lleguen a ser durables. Al contrario, puede suceder que un proceso de liberalización apoyado de alguna manera en los medios, más tarde encuentre resistencia en los mismos medios. Al comentar varias experiencias internacionales de transformación política influidas por los medios el profesor W. Lance Bennett, de la Universidad de Washington en Seattle, apunta: "El advenimiento de las revoluciones de 1989 en Europa del Este sugiere que los sistemas de medios libres son mucho mejores para hacer caer regímenes autoritarios que para luego, sostener democracias estables y participativas" (Bennett, 1998: 195). Tan drástica opinión tiene sustento en la realidad reciente.

Los medios masivos en ningún sentido son panacea de nada. Pueden mejorarla, pero no sustituyen al menos del todo a la política. Tienen una amplia capacidad para informar, pero también para uniformar. Su formidable posibilidad de difusión de masas no significa por sí sola que las sociedades que reciben esos mensajes de tan extensa propagación se vuelvan más sólidas, política o culturalmente.

Los medios, son omnipresentes y tienen más influencia que cualquier otro factor de poder en las sociedades contemporáneas, pero los medios avanzan más rápido que la investigación o la discusión sobre ellos. Así sucede en la relación entre medios y política. Hoy en día, puede decirse, no hay política de masas (es decir, política moderna) sin medios de comunicación. Pero también es posible asegurar que no hay comunicación de masas distanciada de la política.

Decir esto, no es mas que repetir uno de tantos lugares comunes contemporáneos. A nadie se le ocurre ya que en una nación de medianas dimensiones pueda existir política -es decir, creación de consensos, promoción de iniciativas y generación de las condiciones para gobernar- sin la concurrencia de los medios de comunicación. Pero reconocer el carácter político de los medios y, simultáneamente, los rasgos del quehacer político tamizados por ellos, no implica que haya acuerdo sobre cómo debe desarrollarse esa relación. Hoy en día, el debate sobre las responsabilidades de los medios sigue pareciendo tan interminable como estancado.

No hay país desarrollado, o en vías de serlo, de donde no tengamos noticia de que se discute, a veces álgidamente, la función política de los medios. En todos esos debates, hay cuatro temas que son concurrentes, a pesar de la enorme diferencia entre cada situación nacional. Uno de ellos es la concentración de muchos medios en pocas manos. El segundo, la reglamentación de su funcionamiento. El tercero, el de las normas éticas que los periodistas y sus empresas pueden establecer. El cuarto, es el de los medios y las campañas políticas como un aspecto de la relación ineludible entre medios y democracia. A ese asunto se refieren las siguientes páginas.

\section{"SI EL MEDIO ES EL MENSAJE, EL SIMULACRO ES EL MEDIO”}

La relación entre sociedad y medios de comunicación, más definida por complacencias que por discrepancias, llega a ponerse en tensión en momentos de competencia política. La influencia de los medios como nuevas ágoras privilegiadas para el proselitismo es reconocida por los hombres del poder político y sus partidos, en todo el mundo. Ya es tiempo de ubicar en sus auténticas dimensiones a la posibilidad de persuasión que tienen los grandes medios y especialmente la televisión, sobre todo en épocas de campañas políticas. Los medios tienen una capacidad de propagación que ningún candidato político puede despreciar, pero también hay que reconocer que los mensajes drásticos, concisos, que se pueden transmitir por el lenguaje televisivo, son inevitablemente esquemáticos.

La televisión ha contribuido a que las campañas electorales sean más de imágenes que de programas políticos y más de rostros que de ideas, pero ella no ha sido el único elemento para conformar esa tendencia. Los partidos políticos mismos y sus dirigentes padecen hoy, en todo el mundo, una crisis de referencias ideológicas que se refleja en la confusión de proyectos y la difuminación de los parámetros políticos tradicionales. Sin embargo esta crisis, en donde llegan a confundirse izquierdas y derechas, no debiera ser pretexto para que los medios dejaran de cumplir con su responsabilidad de decir lo que ocurre y brindar al ciudadano elementos suficientes para formarse un juicio $-\mathrm{y}$ entonces, estar en capacidad de elegir-.

Ya existe una abundante literatura internacional sobre las consecuencias de la televisión y, en general, de los medios, en las campañas políticas. Pero una de las pocas 
conclusiones al respecto, indica que los ciudadanos no se comportan de manera lineal ante los mensajes políticos. Todo indica que no es lo mismo vender a un candidato que vender sopas Campbell's o Corn Flakes.

Ese allanamiento del fondo, a la forma, se aprecia en la televisión con mayor claridad que en cualquier otro medio. Los dirigentes políticos, e incluso los analistas y comentaristas que comparecen ante ella, tienen que sintetizar sus opiniones en unos cuantos minutos o, casi siempre, en fracciones de minuto. Las propuestas políticas, entonces, se transforman en consignas. La retórica del discurso tradicional, que suele emplearse en las alocuciones cara a cara (en un mitin, o en una asamblea), tiene que ser sustituida por una retórica de los medios electrónicos y sobre todo, de la caja de imágenes múltiples, pero de conceptos restringidos, que es la televisión.

Más aún, Giovanni Sartori ha considerado que la tiranía de la imagen desplaza la fuerza pasional que puede haber en el raciocinio: "En general, la cultura de la imagen creada por la primacía de lo visible es portadora de mensajes 'candentes' que agitan nuestras emociones, encienden nuestros sentimientos, excitan nuestros sentidos y, en definitiva, nos apasionan... la palabra produce siempre menos conmoción que la imagen. Así pues, la cultura de la imagen rompe el delicado equilibrio entre pasión y racionalidad. La racionalidad del bomo sapiens está retrocediendo, y la política emotivizada, provocada por la imagen, solivianta y agrava los problemas sin proporcionar absolutamente ninguna solución. Y así los agrava" (Sartori, 1998: 115-116).

Pensemos en prácticamente cualquier tema: la legislación electoral, la política social, los programas para el campo, la situación de la enseñanza, el narcotráfico. Cada uno de estos asuntos, en los medios electrónicos apenas si puede ser ventilado atendiendo a grandes verdades (que siempre quedan esbozadas a medias) o a propuestas que no da tiempo para explicar. Los debates políticos, cuando se confrontan propuestas de gobierno, suelen ser harto especializados para el estilo sintetizador y, así, inevitablemente simplificador de la televisión. Los detalles de qué artículos y para qué se pretenden modificar en las leyes, considerados en estos términos llegan a ser farragosos y son tomados como materia de interés sólo para los especialistas. Por eso, más que ideas en esos debates se confrontan imágenes.

La televisión exige grandes verdades, no verdades matizadas. El marco de referencia de los televidentes, cuando no tienen por costumbre asomarse a otros medios, suele ser limitado e incluso confuso. La televisión se erige no sólo como medio, sino como escenario de la información que reciben sus audiencias. E incluso, la TV llega a ser protagonista ella misma de las noticias, desplazando a los verdaderos autores de los hechos públicos. El especialista argentino Oscar Landi ha descrito, de qué manera: "La televisión aparece con una doble faz: en primer lugar, tiende a ser habitualmente el escenario principal del conflicto político. En los momentos de apertura política... nos sorprende mostrando la vuelta a escena de los políticos en el living de nuestra casa, esta vez en una pantalla acostumbrada a las ceremonias militares, declaraciones de funcionarios de gobierno y uno que otro 'sano' entretenimiento. Algunos de los políticos demuestran en esas circunstancias su falta de cultura de cámara: es notorio que todavía no manejan el lenguaje del medio. Con el tiempo, ellos y el televidente se irán acostumbrando al nuevo formato de la comunicación política y la importancia de la TV como escenario de la política será menos evidente, precisamente porque ha consumado esa función volviéndola obvia, natural, para todo el mundo" (Landi, 1991: 24).

Las imágenes suelen estar sujetas a interpretaciones diversas. Una imagen no es necesariamente garantía de explicación de una idea o de un acontecimiento. La expresión gráfica tiene tal fuerza que, como mucho se ha dicho en un proverbio adjudicado a los chinos pero magnificado y usufructuado en Madison Avenue -la calle de las grandes agencias de publicidad neoyorquinas-, "una imagen vale más que mil palabras". Aparentemente, no habría mayor objetividad que la de una imagen: el testimonio gráfico de un hecho, tendría que ser contundente. Un automovilista videograbado cuando que se pasa la señal roja y atropella a un peatón, un asaltante a quien se ve esgrimiendo su arma delante de una cajera de banco, o un grupo de delincuentes fotografiados cuando se roban una urna electoral, son indudablemente culpables. Pero la sucesión de imágenes de la televisión, que pueden ser editadas, trucadas o alteradas, no siempre muestra un relato veraz de los acontecimientos.

La televisión tiene una sintaxis peculiar, que puede ser transformada según el punto de vista de sus productores. Entonces, puede haber una modificación en la secuencia original de los acontecimientos. Pero, además, recientemente se ha desarrollado tal capacidad para adulterar imágenes que, merced a un manejo digital, transformando o creando escenas por computadora, se puede mostrar a personajes públicos en actitudes que en realidad nunca tuvieron. La televisión, por sus esquemas simplificadores y ahora también en virtud de sus posibilidades técnicas, no siempre muestra la verdad: puede manipularla, e incluso pervertirla. Con razón, el ya citado Sartori ha alertado ante la tentación de considerar que las imágenes televisivas son sinónimo de objetividad, al descartar "la tan repetida tesis de que el periodismo escrito puede mentir pero el periodismo en imágenes no; la imagen es como es, y habla por sí sola. No es cierto. Si existe la intención de distorsionar o de mentir, la televisión lo logra con una eficacia centuplicada. Para comenzar, en el periodismo en imágenes la distorsión es más fácil que nunca: basta con las tijeras. De cien imágenes se necesita una sola. Si la elección es tendenciosa, incluso Greta Garbo se puede ver afectada negativamente y puede hacerse que parezca fea" (1992: 309).

Y así como la hermosa Garbo puede ser enfocada en sus malos momentos o en sus ángulos menos esplendorosos, 
o incluso su imagen legendaria podría ser distorsionada luego de digitalizada en computadora, cualquier personaje público puede ser videograbado en el momento de un exabrupto, o ser presentado tartamudeando o nervioso. La imagen, que así se mostraría, sería la de un individuo descuidado o alterado. Las consecuencias políticas de esa exposición desfavorable pueden ser grandes.

Mención aparte merece el acoso que, en todo el mundo, los medios de información hacen de los personaje públi$\cos$ aun cuando se encuentran en actividades o sitios privados. En tales actitudes de numerosos medios hay una transgresión a la privacía de los personajes públicos y al respecto existe un inagotado debate internacional que involucra a las capacidades, o a la falta de atribuciones legales, que los medios tendrían para mostrar momentos íntimos de funcionarios, políticos u otras personalidades que no quieren ser retratados o videograbados todo el tiempo ${ }^{1}$.

Cobra auge, entonces, la construcción de imágenes por encima de todo y con rasgos que ha sintetizado el politólogo Fernando Pérez Correa: "Según este enfoque, el motor del comportamiento electoral son los atributos de un candidato sublimados, representados, percibidos: experiencia, seguridad, honradez, frescura, simpatía, prioridades acreditadas con la magia fresca y ensoñadora de la imagen. En suma, la oferta política debe 'transfigurarse', sustituirse por un 'perfil' emblemático, si no seductor, al menos tranquilizante, confiable. La publicidad instaura la relación del candidato con el electorado a través de la metáfora; es decir, las representaciones encarnadas en 'el medio'. $\mathrm{Si}$ el medio es el mensaje, el simulacro es el medio. Candidatos, portadores de propuestas bienhechoras y populares, presentados mediante imágenes combativas, firmes y por lo mismo, inquietantes o impertinentes, son el paradigma de la derrota. Candidatos que ofrecen opciones banales, expuestas con imágenes luminosas, presencias confiables, gratas, son 'vendibles' y los electores los 'compran'. Para encarnarse. La verdad tiene que hacerse figuración: el emblema es la oferta" (1998).

Las sociedades buscan, entonces, tranquilidad más que retos. La trivialización del mensaje público significa, además, la mclubanización de la política: si el medio es el mensaje entonces el simulacro es el medio, dice el autor antes citado. Además, si el medio es el mensaje, la imagen es la política: no la complementa, sino que la sustituye.

\section{POLÍTICA COMPRIMIDA EN SEGUNDOS; LA DICTADURA DEL SOUND BITE}

En su manejo de acontecimientos políticos, la televisión muestra chispazos de declaraciones, discursos o debates que son mucho más extensos. La brevedad de la información televisiva aparentemente ha proporcionado una disculpa a esa actitud, que sin embargo no es suficiente para explicar la simplificación que ese medio ejerce sobre el discurso político. Una ceremonia pública o un debate parla- mentario que duran varias horas suelen ser sintetizados, cuando mucho, en uno o dos minutos en los noticieros de televisión. Así ocurre en el esquema estadounidense de programas informativos, que es el que se ha puesto en práctica en la mayor parte de América Latina y en el cual, en media hora, se proporciona algo más de una veintena de notas. Los acontecimientos políticos, en ese formato, son fragmentados y además, mezclados sin jerarquía clara, al lado de otros asuntos.

El marketing político privilegia el despliegue de frases o, mejor, imágenes contundentes. La mercadotecnia, por definición casi, esquematiza las posiciones políticas, una tendencia que se lleva bien con la discutible suposición de que estamos ante el fin de las ideologías y que implica la simplificación del debate. Más que proyectos se discuten slogans, o perfiles personales. Un par de minutos en televisión, propicia más votos que un recorrido por una docena de ciudades.

Los políticos de todo el mundo asumen ese estilo de los medios electrónicos como una realidad que deben aprovechar, a veces como fatalidad pero también de manera complaciente, en su constante búsqueda de presencia, sobre todo televisiva. En los Estados Unidos, más que argumentos los personajes públicos que pretenden espacio en la televisión procuran manifestar frases ocurrentes, que los hagan aparecer como astutos, brillantes, o conocedores del tema que están abordando. A las frases sueltas que luego son presentadas dentro de una información televisiva se les ha denominado sound-bites, que resulta una denominación tan equívoca como reveladora. "Bite" significa "mordida", o "bocado", pero también, en el argot, puede ser entendido como "engaño" o "impostura".

De esta manera, los sound bites son al mismo tiempo "probaditas" o "golpes" de sonido y también fragmentos que conforman una verdad a medias. La retórica del discurso político, que suele argumentar al estilo clásico -primero la manifestación de hechos, luego la crítica a ellos y finalmente una conclusión o propuesta- queda desfigurada en el manejo parcial que habitualmente hace la televisión al extraer frases sueltas. El sound bite es la reproducción arbitraria de un pequeño fragmento no siempre representativo de un discurso o un debate políticos. Ha simbolizado la institucionalización del reduccionismo del discurso político en la TV pero también, una manera para que las empresas de comunicación establezcan compromisos. Por ejemplo, en la campaña presidencial de 1992 las cadenas de televisión estadounidenses respondieron a las acusaciones contra la simplificación en sus noticieros estableciendo tiempos mínimos de sound bites: la CBS, anunció que garantizaba fragmentos de al

1 De esta y otras vertientes en la frecuente transgresión ética de los medios, especialmente pero no sólo en México, nos ocupamos con detalle en nuestro libro Volver a los medios. De la crítica, a la ética. Cal y Arena, México, 1997. 
menos 30 segundos para cada candidato. Sin embargo, en busca de espacio en los informativos y bajo el principio de que mientras más corta una frase es más televisable, los personajes políticos hicieron esfuerzos para abreviar sus declaraciones.

En 1968 los sound bites en la televisión de los Estados Unidos tenían una duración promedio de 42.3 segundos. Para 1988, habían disminuido a 9.8 segundos (Simon 2, 1996: 133). Los personajes políticos y quienes les escriben sus discursos, no piensan ya en la estructura argumental sino en los chispazos agudos que, sobre todo si son graciosos, o agresivos, les permitirán la gloria efímera pero contundente del sound bite en el telediario vespertino. La política, entendida como el arte de procurar y procesar acuerdos a partir del intercambio de razones, se desdibuja en beneficio de la condensación de todo un acto de campaña en sólo una frase, o un gesto, de pocos segundos. Más aún ahora hay quienes, medio en broma pero medio en serio, llegan a considerar que "el mayor enemigo de un candidato, es un político" 3 .

¿Qué argumentación sobre un hecho público relevante, o qué explicación puede ofrecérsele a los ciudadanos en menos de diez segundos? Los sound-bites que la televisión acostumbra recoger de una intervención política suelen ser aquellos en los que se muestra una frase jocosa, o una expresión ruda, pero no siempre aquella o aquellas que compendien las propuestas, o las tesis, del personaje político cuyas frases alcanzan una oportunidad dentro del noticiario.

Cada vez son más los políticos que se consideran obligados a ofrecer un espectáculo cuando aparecen en público. Otros lo hacen de manera involuntaria. Como quiera que sea, la supeditación del quehacer político al imperio de los medios de comunicación es creciente y obliga a que gestos, frases, propuestas (cuando las hay) y aspiraciones (explícitas o no) sean expresadas para y en los medios, especialmente la televisión y la radio.

Mohines y guiños aparecen con cruda claridad, a menudo drásticamente simplificados, en noticieros y otros espacios mediáticos. Los políticos así retratados, a pesar de sus diferencias, tienden a quedar homogeneizados. En todo el mundo y América Latina no es la excepción, la política suele tener algo de teatralidad impostada y equívocos histriónicos. En 1996, a propósito del escenario político en Italia, el escritor Umberto Eco publicó un agudo artículo en el cual decía: "Antes los políticos se tomaban el tiempo necesario para consultarse, evaluar los pro y los contra de una decisión y en el curso de estos conciliábulos reservados cambiaban de idea más de una vez. Finalmente eran juzgados por lo que habían decidido. Hoy, en cambio, ellos están obligados por la presión del medio a hacer pública cada mínima fase de su proceso de 'ensayos y errores'. Si no lo hacen no aparecen en los diarios y en las pantallas y se ven en desventaja respecto de los que aparecen. Por lo tanto eligen el mal menor (que poco a poco, en sus mentes ya obnubiladas, se presenta como el bien mayor): dicen segundo tras segundo lo que pasa por sus cabezas y que, reconozcámoslo, es muy justo y fisiológico que así sea, excepto que es además patológico que lo hagan público inmediatamente" (Eco, 1996).

Las cuitas y cismas de los políticos no debieran ser noticia relevante. Lo que interesa a la sociedad son las decisiones finales de sus dirigentes pero, con enorme frecuencia, la información en los medios recoge más los regateos, indecisiones y rencillas entre los personajes políticos que sus acuerdos e iniciativas.

La política, al menos tal y como la hemos entendido hasta ahora, fracasa en obsequio de los grandes medios electrónicos. Los personajes políticos no buscan distinguirse por su experiencia, o su liderazgo, sino por la simpatía que sus publicistas son capaces de suscitar entre los grandes auditorios.

\section{"SIMPLIFICACIÓN DEMAGÓGICA". LA POLÍTICA COMO ALTERCADO INTERMINABLE}

Candidatos y partidos, suelen transitar por un sendero muy estrecho, que apenas separa a la retórica, de la demagogia. Tienen la necesidad de mostrar un perfil peculiar para persuadir de que son la mejor opción, al mismo tiempo que descalifican a sus rivales para restarles simpatías. La exposición de ese interés, en los medios, acentúa la rispidez de la discusión política. Más aún, para llamar la atención de sus públicos, los medios suelen presentar cada competencia electoral como un momento culminante, como si en cada votación se dirimiera, siempre, el destino de una comunidad o de un país entero.

El lenguaje con que los presentadores de televisión y radio suelen referirse a las confrontaciones electorales no se distingue mucho al que se emplea para narrar un encuentro deportivo. Términos como "lucha", "lance", "disputa", "batalla", "adversario", "contendiente”, abundan en la descripción de los procesos electorales en los medios de comunicación -y también, por cierto, en el análisis académico de esos acontecimientos: seguramente esta investigación no es una excepción al respecto-. Cuando se tiene un contexto capaz de ubicar la complejidad de esos procesos electorales las descripciones apoyadas en esos belicosos vocablos quedan relativizadas. Pero en los medios, especialmente los de carácter electrónico, en donde junto a unas cuantas imágenes el espectador recibe apenas narraciones muy breves, tales adjetivos adquieren mayor relevancia.

2. Simon ha sido Senador en los Estados Unidos.

3. Aforismo citado por Cid Pacheco, "Marketing eleitoral: a política apolítica”. Comunicacao E política, Río de Janeiro, vol. 1, n.". 1, agostonoviembre de 1994, p. 152. Ese autor aclara, sobre dicha frase, que "como toda caricatura, es una deformación que, no obstante, guarda trazos fundamentales de verdad". 
La exaltación artificial, o en todo caso el abultamiento mediático de las discrepancias, se ha convertido en una de las necesidades de la comunicación de masas para, de acuerdo con sus códigos, hacer atractivos a los acontecimientos políticos. El pensador francés Pierre Bourdieu ha identificado con toda claridad esa "política de la simplificación demagógica” que se produce, dice, cuando los periodistas buscan mantener encendida en todo momento la atención de sus públicos: "cuando el temor de aburrir les induce a otorgar prioridad al combate sobre el debate, a la polémica sobre la dialéctica, y a recurrir a cualquier medio para privilegiar el enfrentamiento entre las personas (los políticos, en particular) en detrimento de la confrontación entre sus argumentos, es decir, lo que constituye el núcleo fundamental del debate: déficit presupuestario, reducción de los impuestos o deuda externa" (Bourdieu, 1997: 128).

Los informadores, entonces, sobreponen sus visiones particulares al interés general de la sociedad; se comportan a partir del contexto que ha condicionado su percepción de los asuntos públicos, que por supuesto es el contexto en el que se encuentran. En palabras del autor antes citado: "son propensos, en efecto, a circunscribirlo todo en un terreno en el que son expertos, y están más interesados por el juego y los jugadores que por lo que está en juego, más por las cuestiones de mera táctica política que por la sustancia de los debates, más por el efecto político de los discursos en la lógica del campo político (la de las coaliciones, las alianzas o los conflictos entre personas) que por su contenido..." (Bourdieu, 1997: 129)

Esa sola circunstancia cancela cualquier pretensión de "objetividad" si es que a tal concepto se le identifica con la asepsia ideológica o la ausencia de intencionalidad en la transmisión de una noticia. Pero no por evidente, esa existencia de intereses y propensiones de los periodistas y los medios deja de ser importante. Sobre todo, porque muy pocas veces tales valores y códigos resultan explícitos para los espectadores de los medios. La aportación de Bourdieu a esta discusión es útil porque no sólo subraya que, en virtud del entorno en el que están ubicados y de su misma formación profesional, los periodistas suelen privilegiar los aspectos más epidérmicos del quehacer político por encima de la discusión de fondo. Además, llegan a tener necesidad de hacerlo así porque, por encima de la divulgación o la explicación, les interesa mantener la expectación de sus públicos. Indudablemente un pleito entre dos personajes políticos, mientras más acalorado y altisonante mejor, resulta más mediáticamente atractivo que la explicación de fondo de las diferencias programáticas que puedan tener

\section{ANTIPOLÍTICA, PROPICIADA POR LA GLAMORIZACIÓN DE LA VIDA PÚBLICA}

La búsqueda del espectáculo suele conducir a los medios a propalar, magnificándolas incluso, las arbitrariedades y tropelías de numerosos personajes del mundo político. Pero esos abusos no han existido por causa de los medios. Al mismo tiempo, la exposición pública de excesos y autoritarismos ha acercado a los ciudadanos a los rasgos más aborrecibles del ejercicio del poder político. El resultado, debido a esas y otras circunstancias, es la pésima imagen que tienen hoy en día los gobernantes y, de manera más amplia, quienes se dedican de manera profesional a la política.

No ha sido extraño, en esas circunstancias, que se propale una antipolítica fuertemente afianzada en la creación de imágenes y personajes de extraordinaria eficacia mediática y que se erige ahora como alternativa a la política tradicional. En lugar de la carrera parlamentaria, o de la experiencia en el servicio público, en todo el mundo (lo mismo en el severo Japón y la vieja Europa del Este que en Venezuela, Perú o Colombia) los ciudadanos están prefiriendo la ausencia de compromisos explícitos y la sensación de castidad y novedad políticas que les ofrecen deportistas, reinas de belleza, locutores y personajes conocidos por virtudes distintas de la práctica específicamente política.

La corrupción real o supuesta, exigua o magnificada, de las élites políticas tradicionales está llevando a estas sociedades a voltearles las espaldas. Y estas élites en los partidos, los gobiernos o los parlamentos, cuando reaccionan lo hacen tratando de mimetizarse con la espectacularidad mediática. Si se trata de competir con personajes de la farándula o del deporte, los políticos profesionales pero regenerados para los medios se preocupan más por el nudo de la corbata o la eficacia del dentífrico, que por los proyectos de gobierno que ofrecen a sus sociedades.

Esa glamorización de la política se empata con la simplificación del discurso a la que nos hemos referido antes y también, con la pretendida abolición de las ideologías que con tanto rechazo académico, pero con tanto éxito mercadológico, fue identificada a comienzos de los años noventa. No compartimos esa tesis pues, de muchas maneras, se puede constatar no sólo la subsistencia de corrientes ideológicas sino, especialmente, la necesidad de coordenadas ideológicamente sólidas y claras. Pero si para tener éxito mediático nuestros políticos modernos privilegian tanto la apariencia por sobre las ideas reducen de tal manera el discurso que más que argumentos esbozan slogans y comparadas unas con otras sus propuestas son entonces prácticamente idénticas; no es exagerado proponer que más que frente al desvanecimiento de las ideologías nos encontramos ante el eclipse de la política, al menos tal y como la hemos conocido en este exhausto siglo y durante el anterior.

Los partidos son, por definición pero además porque hasta ahora no se ha inventado otra forma de organización y competencia reales, imprescindibles. Pero en el fárrago mediático y junto con esa trivialización de la política, a los partidos les va muy mal como actores en los espacios audiovisuales. Los movimientos de ciudadanos, que no buscan 
constituirse (al menos en un principio) en opciones de poder sino en fuentes de presión en beneficio de causas o personajes muy específicos, tienen un atractivo notablemente mayor en la teatralizante escala de valores de los medios.

Más aún: hay quienes en la mediatización creciente de la política identifican un al parecer inevitable desplazamiento de los partidos tradicionales. Si la política ahora ha de hacerse con procedimientos y códigos distintos, impuestos o exigidos por la preponderancia de imágenes mediáticas, entonces es posible considerar que la estructura y el funcionamiento mismo de los partidos tendrían que estar cambiando aunque ello no siempre ocurra de manera intencional, o explícita. El sociólogo Félix Ortega ha descrito así la transformación de la política en España, en donde la liberalización de los medios de comunicación acompañó e incluso apuntaló a la transición democrática en los años setenta: "La llegada de la democracia a España tiene lugar en un momento en el que en Europa se está produciendo la crisis de un modelo de partido (el burocrático de masas, basado en la movilización de militantes y simpatizantes) y su sustitución por otro (el profesional-electoral, basado en el marketing político y dirigido al electorado de opinión). Lo que cuenta ahora es la transformación habida en la comunicación política, en virtud de la cual lo decisivo no es ya el encuentro directo del líder político con sus seguidores sino el acceso al gran público a través de los mass media. Estos son la real correa de transmisión entre los partidos y sus electores" (Ortega, 1998).

El partido de opinión será tan veleidoso como los medios de los cuales depende. Si el sustento básico de los partidos ha girado y ahora ha de encontrarse en los medios más que en sus adherentes estaríamos entre otras transformaciones ante una dependencia recíproca entre instituciones políticas y empresas comunicación, pero ventajosa para estas últimas. El papel de los ciudadanos quedaría relegado ya que, como ha sido harto subrayado, los medios no siempre los representan, de la misma manera que el ser voceros de la sociedad no constituye su vocación más frecuente ni mejor cumplida. El mismo Ortega se encarga de subrayar algunas limitaciones de esa nueva hechura de los partidos: "Ahora bien, este tipo de partido es una institución débil. Primero, porque los políticos no basan preferentemente su liderazgo en la organización del partido, que pasa a un segundo plano frente a los grupos de interés y a las propias necesidades de la comunicación política. Segundo, porque no es el partido quien proporciona la subcultura política a los electores sino que la misma, en la medida en que existe, es un efecto de esa misma comunicación política" (Ortega, 1998).

Estaría construyéndose, así, una "democracia de opinión" que tendería a sustituir no a la institucionalidad estatal ni a las reglas formales de la competencia electoral, sino fundamentalmente a los mecanismos merced a los cuales se crea, registra y/o establece la legitimidad en las sociedades contemporáneas.
Quizá los medios tiendan a desplazar a los partidos. Más aún, puede ocurrir que, por efecto de los medios, los políticos no les hagan demasiada falta a sus públicos y no debido a desacuerdos ideológicos, sino a la lógica del espectáculo. Ignacio Ramonet sugiere, de manera contundente: "La televisión se instaura como el ágora central de la vida política; impone a los políticos la necesidad de adquirir, frente a las cámaras, una expresividad completamente teatral. El efecto del dominio del discurso y del cuerpo se revela cada vez más indispensable. Por otra parte, convertida efectivamente en medio de masas, la televisión convierte en caduco, superado, todo lo preexistente. Por efecto de ruptura, provoca una especie de amnesia en el espíritu de los nuevos telespectadores. Para éstos, el mundo tiene ya dos tiempos: antes y después de la televisión. Los políticos que no aparecen en la pantalla no tienen existencia real" (Ramonet, 1997: 202).

Esas transformaciones en los protagonistas y los espacios del quehacer político, pueden alcanzar consecuencias todavía mayores. El prestigiado investigador Néstor García Canclini encuentra que, además, se ha producido "el desvanecimiento de los espacios políticos de negociación”. Y explica: "Los espacios públicos, como el parlamento, y las acciones de base, que podrían llegar a mítines y manifestaciones callejeras, huelgas y enfrentamientos físicos entre los actores de la sociedad civil y los poderes gubernamentales, daban a las negociaciones formas de interacción 'concreta'. Ahora, la conflictualidad social y la gestión de sus transacciones se desplazan a lugares herméticos, a fuerzas que los ciudadanos no pueden enfrentar. ¿Dónde y quiénes pueden tomar decisiones cuando una campaña electoral cuesta millones de dólares y la imagen de los candidatos no se basa en programas doctrinarios sino en adaptaciones oportunistas sugeridas por los estudios de marketing político?" (García Canclini, 1995: 180-181).

Cuando, de esa manera, el marketing desplaza a la negociación y la videopolítica a los espacios públicos es posible que estemos en una etapa en la que resulte necesario volver a pensar cuáles son los sustentos de las democracias modernas. Formalmente, los ciudadanos y el sufragio siguen siendo el motivo y la fuente de legitimidad de los sistemas políticos. Pero ni el trato entre políticos y ciudadanos ni, en ocasiones, la relación entre la gente y los asuntos públicos son tan directos como antaño. Los medios de comunicación se han convertido en los mediadores políticos más importantes, desplazando en esa función a los partidos.

Desde el mundo de la política se ha tomado a esa nueva situación con tardanza y resignación. Y junto con esa presencia de nuevos mediadores se registra un deterioro aparentemente inevitable en la percepción que la sociedad tiene de los hechos públicos. Los tráficos de influencias, los abusos y hechos de corrupción de los personajes políticos, son la causa principal de esa imagen que los medios suelen desplegar y vender con gran inte- 
rés. Pero, además, la desacreditación de los asuntos públicos parece estar relacionada también con la espectacularización de la política: si la política y los políticos forman parte del espectáculo mediático, el público tiende a tomarlos con tan poca seriedad como la que destina a otros entretenimientos.

\section{LA PROTESTA, EN TELEVISIÓN, ES MÁS VISTOSA QUE LA POLÍTICA}

La relevancia política de los medios es más que palmaria. Lo que no parece tan claro es en qué medida el imperio de las imágenes desplaza a las redes de relación tradicionales entre los partidos y la sociedad. Lo menos que sucede es que esas redes se complementan con la intercesión de los medios. Pero es difícil aseverar que los partidos estén plenamente desplazados por los medios.

El aislamiento, o el debilitamiento de los partidos, también está relacionado con la manera como la política tiende a ser retratada por los medios. La protesta es más vistosa que la política. $\mathrm{O}$, para decirlo de manera menos drástica, la reclamación coyuntural es más mediáticamente intensa que la anticlimática política institucional. Una batahola callejera o incluso la imagen de un activista que pancarta en mano despotrica delante de las cámaras tiene mayor impacto mediático que un atildado funcionario leyendo un documento detrás de la consabida batería de micrófonos. Los enredos son noticia; la democracia no.

La vulnerabilidad de los sistemas políticos ante los medios se debe también a la falta, o la deficiencia, de una política de comunicación. Así: "En ausencia de una política de comunicación social para orientar la transición política, lo sorprendente es que las democracias novatas al estilo de 'una persona, un voto', rápidamente sean víctimas de demagogos, nacionalistas y autoritarios. Los nuevos propagandistas le recuerdan a la gente las virtudes nostálgicas del viejo régimen mientras señalan a los nuevos enemigos domésticos..." (Bennett, 1998: 204).

Ninguna de estas constataciones ofrece remedios al círculo vicioso medios estrepitosos/políticos mediatizados que se puede apreciar hoy en día. Las soluciones están por construirse y no dependen sólo de los medios. Éstos, por lo demás, hacen muy buen negocio cuando la política les ofrece espectáculo para solazar a sus públicos y usufructúan con enorme alegría el papel de mandarines de la vida pública en el que su capacidad tecnológica y la debilidad de la política institucional los ha colocado. Y los políticos, fuera de tratar de mimetizarse al imperio de los medios o quejarse de ellos, según les vaya en las encuestas y los ratings, no se esfuerzan por entenderlos.

¿Existen opciones delante de la mediatización de la política? Hay viejas fórmulas, no siempre del todo exploradas en todas nuestras sociedades, que pueden ser útiles en la reconstrucción o en la reforma de este panorama: los medios públicos, capaces de constituirse no en antagonis- tas pero sí en contrapesos de aquellos con prioridades fundamentalmente mercantiles; la ética y la responsabilidad tanto en el poder político como en los medios y que en el caso de la prensa, amerita de códigos e incluso también instituciones de autorregulación; la discusión abierta de los yerros y excesos de los medios pero con afán pedagógico y no vindicativo; la diversificación de medios que no abate la preponderancia de las grandes televisoras pero que les impone un nuevo contexto -eventualmente competitivo, a mediano plazo, gracias a opciones nuevas como la interactividad que es posible en la Internet-. Quizá, en efecto, sea preciso pensar en la política por otros medios: no a través de, sino en busca de medios distintos para propagar ideas políticas.

También podría procurarse y esa sería una tarea de ambas partes, la desteatralización de la política en los medios. Pero esa, a estas alturas, no puede ser tarea sólo de los políticos, ni sólo de los comunicadores. Todos ellos, en todo caso, no serían nada sin la sociedad. Pero eso, a ambos, se les olvida con demasiada frecuencia.

\section{BIBLIOGRAFÍA}

FERNÁNDEZ, Eduardo (1996): “Medios de comunicación, ¿’sustitutos de la actividad política?”. En Contribuciones, 2 (50) abril/junio, 19 y ss. Buenos Aires: Konrad Adenauer Stiftung,

NeIL Collins y Patrick ButLer (1996): "Positioning political parties". En Press/Politics, 1: 2. Cambridge: Spring.

BennetT, Lance W. (1998): "The Media and Democratic Development: The Social Basis of Political Communication". En O'NeIL, Patrick H. (ed.): Comunicating Democracy, The Media E Political Transitions. London: Lynne Rienner Publishers.

SARTORI, Giovanni (1998): Homo videns. La sociedad teledirigida. Madrid: Taurus.

LANDI, Oscar (1991): "Videopolítica y cultura". En DIALOGOS de la comunicación, 29, marzo, 24-35. Lima: Federación Latinoamericana de Asociaciones de Facultades de Comunicación Social (Felafacs).

SARTORI, Giovanni (1992): "Videopoder". En Elementos de teoría política. Traducción de María Luz Morán. Madrid: Alianza Universidad.

PÉrez CorreA, Fernando (1998): “Opinión pública y democracia”. En Etcétera, 281, 18 de junio. México.

Simon, Paul (1996): "From Inside the Beltway. Perspectives on Campaign '96”. En Press/Politics, 1: 1. Cambridge.

ECO, Umberto (1996): "Televisión, telepatía y vaivenes políticos". En La Nación Line, http://www.lanacion.com.ar.

Bourdieu, Pierre (1997): Sobre la Televisión. Barcelona: Anagrama.

García Canclini, Néstor (1995): Consumidores y Ciudadanos. Conflictos Multiculturales de la Globalización. México: Grijalbo.

Ortega, Félix (1998): "Del auge del periodismo". En etcétera, 301, 5 de noviembre. México.

RAmONET, Ignacio (1997): Un mundo sin rumbo. Crisis de fin de siglo. Madrid: Temas de Debate. 